\title{
Archbishop Warham's Visitation of Monasteries, I5II
}

SINCE the publication of Dr. Jessopp's volume of 'Visitations of the D Diocese of Norwich, 1492-1532,' ${ }^{1}$ the general nature of the results that may be expected from a further study of these documents is now well known as far as that period of monastic history is concerned. But although the complaints brought to light in Warham's visitation of the diocese of Canterbury are remarkably similar in character to those of the Norwich visitation, fresh evidence for different districts is still desirable, and even if the publication of these documents be not otherwise useful, they at least give precise details on the number and names of the inmates of many houses which cannot be obtained elsewhere. Some account of Warham's visitation, is, however, specially desirable since the statements made by Mr. Froude' are misleading and have been copied by others. Speaking of Morton's visitation, 1499, he says, 'Evils so deep and abominable would not yield to languid treatment; the visitation had been feeble in its execution and limited in extent. In 1511 a second was attempted by Archbishop Warham. ${ }^{3}$ This inquiry was more partial than the first, yet similar practices were brought to light : women introduced to religious houses; nuns and abbesses accusing one another of incontinency; the alms collected in the chapels squandered by the monks in lieentionsness. Once more, no cure was attempted beyond a paternal admonition.'

These statements are not warranted by the manuscript evidence of 'Warbam's Register' to which Mr. Froude refers. In one monastery only, Faversham, is there the complaint made that women have access to the cloister and refectory, 'and are not shut out as in other monasteries ;' and an injunction is issued that they are not to be admitted, and that no monk is to speak to any woman in the nave of the church. There is not a single charge of any kind of immorality brought by one monk against another. One such charge is brought by a prioress against her nuns (St. James', Canter-

- Camden Society, 1888.

History of England, ii. 309.

- He refers to Warham's Register, manuscript, Lambeth.

- Lambeth Library, in the volume marked 1503, $t .95 \mathrm{a}$ 
bury ${ }^{5}$ ) but as will be seen below it is of a perfectly frivolous character. Of money of any kind 'squandered in licentiousness,' there is no hint. The seventeen establishments visited contained altogether one hundred and forty-seven monks, ten novices, and twenty-six nuns in four houses. The numbers are certainly small, eighty of the one hundred and forty-seven being monks of Christchurch, Canterbury ; but as the small houses were believed to be the worst managed, the absence in this district of any charges of a gross character is of importance. The complaints made by inmates of the Norfolk houses (of which, however, a larger number were visited) are of a much worse kind. It is, of course, quite possible that the visitations do not give a fair picture of the life even of the monasteries visited; yet the rambling and gossiping answers of the witnesses, who were taken secretly and separately, bear obvious traces of haman nature. Still though the brethren and sisters are very human in their complnints, and were there to complain, backbiting and slander do not seem to have produced any very serious charges in the monasteries of Kent. Setting aside, however, the broad issue of the state of morals in religious houses at the beginning of the sixteenth century, much information is afforded about other aspects of the religious life at this date. It becomes fairly obvious from such answers as are given here, that what the inmates chiefly cared about was the amount of their pocket-money or 'stipend.' One answer gives it as a plain fact that the examinee knows no one will enter that house for choice, because the pension is paid to each monk in kind, not in money. The conception of community of property as an element of the monastic life had been entirely dismissed, and the amount of the monastic endowment became an important consideration in choosing a house as an abode. Though there is nothing in these complaints that points to laxarious living, grumbling at the food and drink is usual. Meat is no longer prohibited, and the monks direct their attention to the way in which it is boiled and roasted. The services of the house are no longer undertaken by its inmates, the butler is in two cases not a monk', and the nuns in one house complain that not one of their body will undertake the office of 'Convent Servant,' and all their weekly 'stipends' are reduced because they have to get a woman in from the town.

I have contented myself with giving an abstract of the testimony which was brought forward as an illustration of the character of monastic life.

The formal matter of the visitation of Christchurch, Canterbury, consists of, first, the mandate directed to the prior and chapter, in which the archbishop gives notice of his intention to visit the metropolitan church of Christ, the prior and monks and others below.

- This nunnery is not named in Dugdale. It was founded for leprous sisters : see 
leading the religions life there, the clergy and people of the city of Canterbary, both in hend and in members, to the honour of God and for the salvation of sonls. He proposes to correct those defects which shall be discovered to require reformation. He therefore cites the prior and all the monks of the church with those leading the religious life there to appear before him in the chapterhouse of Christchurch on Tnesday next after the feast of the Nativity of the Blessed Virgin Mary, namely, 9 Sept., and on as many days following $\mathbf{a}$ may be necessary. The archbishop defends his right of visitation by inhibitions. The prior and chapter are to give in the names of those cited, distinctly and fally, in a schedule attached to the citation. 'The mandate is issued at the manor of Knole, 17 Ang. 1511. Secondly, the prior and chapter certify the names and surnumes of the monks of the cathedral church under the common seal of the prior and convent. They acknowledge the receipt of the mandate and quote it in fall. Then follows the schedule containing the names of the monks and novices. ${ }^{6}$ On 9 Sept. the archbishop began his visitation in person in the chapterhouse after the prior had solemnly celebrated innss.

A sermon followed, the preacher is named and bis text quoted. The sermon over, the prior showed the schedule of names which was publicly read sloud by Cuthbert l'unstall, doctor of laws and chancellor of the archbishop. 'The archbishop then proceeded to examine singly and secretly the prior and monks. Their com-

- They are:-John Broke,' James Burton, John Lee, Richard Marchall, ${ }^{2}$ Henry Northgate, Richard Copton, Richard Dergng, William Chichele, John Salisbary, Henry Addisham, William Ingram, John Goldyngtone, William Molasch, John Waltham, John Menya,' Thomas Ykham,' John Antony, Roger Benett, John Budbary, William Chartham, Thomas Asche, John Dunston, John Hensfeld, Nicholas Clement, Alexander Stapall, Thomes Anselme,' John Apuldore, Thomes Goldwell,' in studio Parisiensi, John Barne, John Dover, John Garrard," Richard Feversham, William Wynecheppe, William Gyllyngham " ir studio Parisicnsi, Richard Bokyngham, John Wykham, John Langdon," William Taylor, Nicholes Hulle, Thomas Lee, John Crosese, Thomas Hawkerst, John Wednybborowe, Edward Bokyng Oxonie, John Schepey, John Newbery, Walter Hartford, James Hartey Oxonie, Richard Tonge, William Croston, William Sellyng Oxonic, William Brdley "Oxonic, William Farley, William Bredgar, John Morton, Thomas Goldstone," Thomas Bekett, = John Oxney, ${ }^{+}$William Wyngham, John Wynchilse, Anthony Horden Oxonic, Jasper Copton Oxonic, Jobn Elphe,' Robert Boxle,' Robert Fonteyne, Gervase Crambroke, Roger Estry, John Elham, William Pelham, Thomas Wylfryd," Guy Chillynden, William Lichfeld," llichard Godmersham,' Richard Bonyngton,' Nicholas Harste,' John Holyngborn, Edmund Marchall, John Lamberherste, John Aschford [in all geventy-nine names. Of these probably not all were resident, six were at Oxford, two pursuing their studies in Paris.] There were also'eight novices, not professed, Richard Thornden,' Laurence Nunam, William Petham, Robert Otford, John Sarisbury, Robert Holden, John Charte, ${ }^{4}$ and William Sandwich."

\footnotetext{
- The opelling of the armames in that of the manascript. Where tro rerdoul are given, and one arees with the modern form, the modern is acoepted.

A mont at the time of the distalation.

- Third prior at the dianolution.

- Monks at the diveolation.

- Boxlog. Dugriale, L 112 Yaster of the table at the disuolation.
} 
plaints are not given. On the following day, the archbishop, sitting in the chapter-house, ordered the prior and monks of the church holding offices to give in their accounts of the state of the house by 1 April. There were present, besides the prior and chapter, Cuthbert Tunstall, the archbishop's chancellor, Thomas Baschurche clerk, and William Potkyn, public notary. The archbishop then gave power to Thomas Goldstone, prior of the monastery, Thomas Yckham, preceptor, John Waltham, granger, John Salisbury, master of the table, William Ingram, penitentiary, John Dunston, granger, and John Bukyngham, fourth prior, to reform those general defects discovered in the said visitation.

Then follows an inquiry into. the chaplaincies of the diocese which does not belong here. The remaining visitations are all similar in form to that of Christchurch with the addition of the injunctions. They begin with the mandate, which is followed by the citation, the reply to the mandate, the schedule of names of members of the house, the date of the visit, in what part of the house the meeting was held, the name of the preacher and his text. After the citation, sealed by the common seal, has been rend aloud, the visitation proper begins, the complaints of each inmate are heard, and injunctions issued for the correction of abuses. The proceedings end with a notice from the archbishop that the visitation will be renewed on a certain day or thy day sooner or later that it may please him to appoint.

\section{Canterbury. St. Gregory. ${ }^{7}$}

'l'homas Well or Welles, for six years prior, was examined on the condition of divine service, on the observance of the rule of St. Augustine, and on the number of the brethren. ${ }^{8}$ Walter Canterbury, subprior, says that William Tailor is fond of squabbling with the brethren, in his office as precentor. He fears that if he is allowed to remain in office there will arise much contention among the brethren. In the absence of the prior and subprior, he acte as president of the chapter; there are others better fitted for this office. The sulsprior says further that the prior does not give the items of his account to the brethren, it is a general and not a special account. If the brethren may not inspert the nccount they do not know the state of the priory. William Dover, Edmund Favershaw,

T'Tomas Welles (Episcop. Sidon; Dugdalo, vi. 614) is the prior, Walter Ceutcrharg, subprior; tho monks aro Willism Dover, Edmund Farcrshan, sacrist, Willinm Tailor, precentor, John Cumbridgc, Stephen Cobham, Dansten Northgate, William Braborne, William Hadely est studess Cautabriggie, ten in all. The sarmon at the visitation was preached by John, bishop of Cyrene.

The archbishop of Canterbury had fonnded the house. Inanfrano had ordered it to maintain six secular priests and twalre clerks. Archbishop William in the time of Henry I made it a House of Canons Regular. 
sacrist, and William Tailor, precentor, agree with the subprior about the accounts. John Cambridge says the prior will not give the account in writing, but only verbally. He says also that one John :Humfrey, batler, ${ }^{9}$ gives the brethren very poor beer (servisiam nimis tenuam [sic]), contrary to the prior's wish. He agrees with the subprior about the preceptor. Stephen Cobham anys the precentor is a great sower of discord amongst the brethren, and is unfit for his office as he does not know how to sing. Dunstan Norgate or Northgate says the same. They have also no bell-ringer, so that the brethren are abeent from divine service not knowing the timc. The injunctions order the prior to observe his rule and to show his accounts annually in writing to the brethren, and all other officers are to do the same. The accounts must also be shown to the archbishop on 1 April, together with an inventory of all the goods and the jewels of the priory at the time of his accession to office. The prior is to tell Tailor not to squabble, on pain of removal from his office.

\section{St. Sepulelure.}

'Ihe third mundate is addressed to the prioress and convent of nuns of St. Sepulchre, Canterbury. Mildred Hale is its prioress. The rule followed is that of St. Benedict. The prioress says they do not rise for matins in the middle of the night but at dawn, be. cause the doors of the cloister are being mended, and the roof is being covered, and there is so much noise outside the church. Johanna Hamstede agrees with the prioress. The other four nuns are Agnes Stabilgate, Margaret Isacke, Katherine Preston and Philippa Jane. ${ }^{\text {I0 }}$ The injunction orders proper accounts to be giren.

\section{St. James.}

The house of Sisters of St. James or St. Jacob" outside the walls of Canterbury is visited by Tunstall. Dame Agnes Yuys, the prioress, is seventy-four years old. They do not have bread and wood as they ought to have, owing to the fault of the subprior of Christchurch, Canterbury. They said this before in the last visitation of the house in the presence of the said commissioner. The prioress complains that Richard Welles stays to talk in the precincts of the house, and his wife sells beer in the precincts. They are very quarrelsome people, brawlers, and sowers of discord. There is always a crowd of people at the house of Richard. Joanna Chambers is eighty-four year's old, and has been forty years and more $n$ sister of the house. Alicia Bromfield is

- Sot in the list of monks.

1. The last prioress. Daydale, iv. 414.

1 This house is not named in Dagdale. It is given in the Sib. I'opog. Brit., in Dinncambe and Batteley's Antinutitios in Kont, p. 428, as a hospital for twenty.five leprous sisters, a prioress, three prieste, and a clert. 
eighty, a sister of eighteen years' standing, Editha Keme is thirtysix, Joanna Croche fifty, of fourteen and three years' standing respectively, all examined singly, say the prioress is a 'diffamatrix' of the sisters. She says publicly in the neighbourhood that they are incontinent 'et publice meretrices,' to the great scandal of the house. The injunctions order the prioress in future not to ase contumelious words to the sisters, neither publicly nor privately. To all the sisters it is enjoined to be obedient and attentive to the prioress as their statutes and profession require.

\section{Wengham College.}

The next visitation is that of the Prior and Canons of Wengham " College, 16 Sept. Henry Ediall, prior, examined, says the foundation is for eight vicars choral, and now there are four. ${ }^{13}$ Next that each canon at the end of the first year of his residence is bound to give to the college an 'ornament.' Also each canon ought to serve his term of residence in his own house and at his own table, which none observe. The house of Ambrose Payne, a canon, is in need of repair and in fnct rery ruinous. The prior has two incompatible benefices, and has to show a licence to hold in plurality at Lambeth at his next coming. William Roger, chaplain of Asshe, is found to be a Cistercian monk of Boxley, in the diocese of Canterbury. Though he showed his abbot's licence, he may not dispense with the monastic habit. John Joliff, professed of the monastery of Evesham for fourteen years, showed a papal dispensation to drop the monastic habit, bat the archbishop did not admit him to do so. One Brother Christopher is warned in future not to celebrate in the chantry of Asshe but to return to his cloister. The rest of the visitation of this collegiate church has no connexion with monastic history.

\section{St. Martin's, The New Work, Dover.}

The next mandate is directed to the Prior and Convent of St. Martin's, The New Work, Dover. ${ }^{14}$ Thomas Shrewsbury, ${ }^{16}$ professed

A MS. Wynghan. Dagdnle, ri. 1341, says it was originally founded for ten canons or prebendaries, afterwards reduced to six.

12 The canons are Ambrose Payne, Thomes Kerg, John Williams, Robert Wodward, Thomas Diffeld, and Robert Coppar. The vicars choral are Thomas Bartelott, John Millett, John Gellyfi, and Robert Dobbys. The pensioner is Thomas Pennorke, alias Glover. The choral clerks, John Beche, Richard Banes, John Morys, William de Latours. The wardens, Edward Orenden, Thomas Pynder. The parishioners, John Derys, John Perys, Thomas Horres, and Richard Skelton.

"Founded 1139. A cell to the Priory of Christchurch.

is The prior is John,' Bishop of Cgrene. Thomas Shrewsbury is subprior, and the monks are John Goodwyn, John Cornwell, chaplain, Richard Dover, cellarer, John

I Thornton or Thorden, safragan of the archbichop of Canterbury. Dugdale it. 630, note 1. The

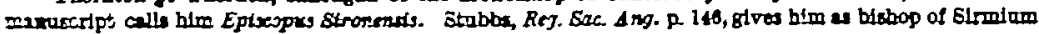

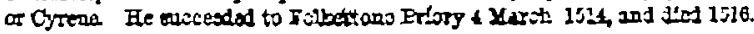


for eleven years, says the monastery is in many places in ruins for lack of repairs. The officers of the town of Dover deprive the house of its mortuary fees. The brethren who hold office are allowed continuous access to the town. If they go, the prior warns them against eating or drinking there. Johu Goodwyn says the officers of the town do injury to the n:mastery. The cellarer and other officers hare access to the town, so the monastery is defamed among the seculars, and they are enjoined not to go there. John Copledyke deprives the monastery of certain lands near Dover castle. Nicholas Templeman, mayor of the town, and its citizens last year damaged a mill and diverted the course of water belonging to the monks. 'This mill and water belonged to the monastery from its first foundation. The last prior laid the monastery under a debt of ten pounds to William Marchall for an annual pension to last during Marchall's life.

The result of the visitation was that a memorandum was mado that William Marchall, vicar of Apledore, be asked to show the essignation of his pension at Aldington. All those with offices which aro held ad compotum are to give an oath to render accounts faithfully, both those now elected and thoso clected in future. The mayor and citizens of the town do injury to the monastery by depriving it of the mortuaries of the church of St. Martin in the town. John Cornwell says the same about the mortuaries. They belong to the monastery from its first foundation for the repair of the chancel of the church of St. Martin, which the prior and convent are still compelled to repair. One Thomas, rector of Charleton, deprived the house of its tithes due from the parish of Buckland. Richard Dover, cellarer, John Canterbury and John Elham, third prior, say the seme about the mortuary fees. William Hethe says there are three novices who are not taught grammar, and that there is no teacher but the subprior; he reads the Gospel twice a week to them. and nothing else. He makes the same charge against John Copledyke as does Thomas Shrewsbury. Richard Bourn, precentor, says the lands and tenements of the house are in ruins and its emoluments diminished on account of the negligence of the present prior's predecessor. Alexander Dover, novice, says that the third prior panishes for very slight offences, and charges them with groundless offences (et finxit contra eos nonrullas offensas indebite). Another complaint is that they have linen sheets (lintheamina linea) and not of wool (et non de stamyn) according to St. Benedict's rule. They have no preceptor to teach them grammar. Thomas Colman and Thomas West, Wescot or West-

Canterbury, John Elham, third prior, William Hethe, sacrist, Richard Bonrn, pre. centor, Alexander Dover. Thomas Colman, Thomas Wescot. Thomas Elham und IVilliam Saltwood, ' agrantes in aposteria.' The house belongs to the $B$ nedictinc order. It was rea d 18 Sept. and the prior bishop was examined. 
court, both novices, make the same complaint that there is no teacher. Westcourt complains that they sleep in linen sheets.

The injunctions order the prior not to let his brethren go into the town or city of Dover without his special licence, or, in his rbsence, that of the subprior, and if any of the officers go out, for instance, the cellarer or other officers for the convenience of the monastery, they are not to eat nor drink in any house lest there arise any dissension between them and the officers of the town. All the canons after they have retired from the refectory are to go immediately to the dormitory according to the rules of their order, and if any officer be absent for a legitimate reason, he must not be outside the dormitory after the eighth hour of the night without the prior's leave. The reverend father enjoins on the monks singly that they do not go to the town except as above directed, under pain of excommunication. 'The prior must not give leave for this purpose to any monk, except for urgent and legitimate cause. To the monks the order is given to go to the dormitory before the eighth hour, i.c. immediately after they leavo the refectory. The officers who ought to render accounts are enjoined to do so faithfully and annually under oath taken on the Holy Gospel in person at the time of their first admission to any office. ${ }^{16}$ The prior is to provide an instructor to teach the novices and monks grammar immediately, if he can do so conveniently. The novices are to do work in the grammar school three days in the week. The monks are on no account to use linen, bat woollen both for sheets and for shirts (nullo modo utantur lineis sed stamyniis, tam in linthiaminibus quann camisiis.) The prior and officers are again enjoined to make a full and true account of the state of the whole monastery, and an inventory of all the goods, jewels, and ornements, which inventory is to be shown before the octave of Enster.

\section{God's House, Doter.}

The next mandate is directed to the Master and Fellows of God's House, Dover, ${ }^{17}$ which was visited Sept. 20.18 The archbishop warned Simon Tempilman that he was not to celebrate mass or fulfil

16 In 1585 the commissioners spoke well of the house, though Lagton says "the prior of Dover and his monks be even as others be, but he be the worst of all.' (Gasquot, Henry VIII aukl the Englis/ Mlonasteries, i. 364.) Tho commissioners baid :-.-' The House of Dovour is a goodly house and well repayred in all places, as far as we cowd perceyve; an that the prior (as itt was reported unto us) flound the houso att his ffyrst comyng thither indented in ix"li, and hath reduced and brought that to cli as itt is said, of whose nowe case dyverse of the honest inhabitantes of Dovour sherse them selves veray sory.' Wright, Suppression of the NFonasteries, p. 80. Thornton then fras no longer prior. The quarrel with the Dover citizens seems to beve been made up.

17 Hospital of St. Mlars, Duglale, vi. 65j.

11 The master is John Clerbic ; the socii are the following :- Fincent Barley, 'Thomas Fuller, John Hobbyng, John or Thomas Knight, Jobn Saltar, brethren and priests. 
any ecclesiastical function in the diocese of Canterbury or elsewhere, under penalty of excommunication, after next Michaelmas. Then afterwards this Simon obtained a certain dispensation to obtain a benefice, and was instituted to the benefice of Leigh in the diocese of Rochester. Simon appearing before the reverend father in the chapter-house of God's House at Dorer, begged to be admitted to the brotherhood of that house, and to have a stall in the choir and a place in the chapter, saying that he wishes when he pleases to reside in his benefice, and when he pleases in the said house. The reverend father then asked the master and brethren of the suid house, whether they wished to receive him into their house as a brother according to his petition, to which all the brethren and the master, examined separately, said that at the time when he was in that house and was a brother, he was so quarrelsome, brawling, and litigious with the master and his brethren, that religion could not be properly observed in a laudable way, and there could be no charity amongst the brethren, and therefore the said master and brethren humbly beg the reverend father then and there not to admit him as a brother to the house, fearing that if he be admitted, there may be a total dissolution of charity amongst them in future. Then the said reverend father warned this master Simon, that immediately after the vigil of St. Michael next ensuing he might enter his parish church aforesaid, but that he should not undertake any service in the diocese or immediate jurisdiction after the said vigil, and that any service already accepted he must leave immediately after the said vigil. Vincent Barley, brother of the said house, examined, says that whereas according to statute, brethren of the house should have an annual meeting (toga) to announce their pensions, that meeting is not held. Thomes Fuller says as Barley deposes, and also that the master tells them the state of the house verbally only, not in writing and does not give the particulars. John Hebbyng, Thomes Knight, and John Salter all say the same. The injunction orders the master to communicate to each of his brethren the amount of their ' exhibitions' in a congregation (toga), and that he certify the same to the reverend father before the feast of All Saints. He must also gire proper accounts.

\section{Folliestone.}

On 22 Sept. the Priory of Folkestone ${ }^{19}$ was visited. William Weston, a monk there, says that he was first professed of the order of st. Augustine in the monastery of the Blessed Mary of Overey, in Winchester Diocese, and then of the order of St. Benedict ut Westminster in the presence of James Burton, now a monk of Folkestone, and administrator of spiritual and temporal goods by

wo Of the ordar of St. Benedict. Irugdale, ir. 672. 
the authority of the Reverend Father before the next feast of All Saints. James Burton without any delay certified the said reverend father in writing of his letters licensing him to migrate from his diocese (litteris dimissorialibus). Thomas Seale was professed, as he asserts, of the order of St. Benedict in the monastery of Bermondsey, in Winchester diocese. He is ordered to show his dimissorial letters and the above-named James Burton is to do the same to certify that all is correct. John Carter was professed as he asserts of the Premonstratensian canons in the monastery of St. Rhadegund in the diocese of Canterbury, and then was professed of the order of St. Benedict in the monastery of Folkestone. He also is to show his licence. James Burton is hereupon injoined to make a full and true account and inventory. ${ }^{\circ}$

\section{The College of Wyc.}

The mandate to the Naster and Fellows of the College of Wye gives the name of the master, John Goodhew, who showed his letters of ordination, collation, and institution to the parish church of Staplehurst. A note is made that he has no papal dispensation for tro incompatible benefices. 'Thomas Martin is conductus: und William Gowlaw or Gowrlaw is a Scotchman (scotus). It is discovered that the Master of the College frequents in a suspicious way the house of John Stephens of Herne Hill in the deanery of Ospring. A note is made that there me diverse detecta against him as appears in the bills of the deanery of Ospring, of which the Canterbury commissioner has copies..

\section{Davington. 29}

Matilda Awdeley is prioress and shows ler inventory. They have rents to the value of 31 . 14s., besides demesne lands which they hold and cultivate, to the value of $10 l$. a year. The house

- In 1585 the commissioners speak well of it: "The house of Folkston is a littill house, well repayred, and the prior a veray honest parson, and a veray good husbond,' and no les belovyd amonges his neypours' (Wright, Stupression of the Monasterics, p. 89). Bat Dr. Layton found the prior (Bessett) a most iniquitons person (Gasquet, p. 304).

31 Thomas Rogers, sucizs, Thomas Penycokc, curctus, Williain Gowlaw, Thomas Martin belong to the house. The names of the clerks are Richard Mount, John Bate, John Freman, Thomas Densse the names of the choristers, Nicholas and Richard Freman, Robert Weever, and John Maister. The visitation was held 25 Sept. in the 'vestibule.'

:- Davington or Daunton, near Faversham, of the Benedictine orler. The nuns had for some time suffereal from poverty. 'At last, in the 27th of Henry the Eighth, it being found before the escheator of the county that neither prioress nor nuns werc left in the numnery to perform the services of the foundation, the house lapsed to the crown, tanquam locum yrofunum et dissulutumb.' Dugdale, Mon. is. 288. This mandate to the prioress and convent of nans at Davington, dated 27 Scpt., gives tho names of nuns, Dame Elizabeth I wdeley and Elizabeth Bath, both professed ; Agnes Cloment and Elizabeth Rickard, not protessed. 
has to pay 208. to the archbishop for board at the time of his visitation. Elizabeth Awdeley, professed at Cambridge, has been here twenty years. When examined, she says everything is done well in the house and according to their rule. Elizabeth Bath, professed of the monastery of Malling (Benedictine), in the diocese of Rochester, has been here ten years. On examination she says the rents and revenues of the house derrease owing to the guilt of the officers. As to other matters in detail all is well. Agnes Clement, not professed, has been there fifteen years and says all is well; Elizabeth Rickard, not professed, an inmate for ten years, the same.

[No injunction follows.]

\section{God's Housc, Ospring.}

On 28 Sept. the visitors were at God's House, Ospring, in the diocese of Canterbury. Master Woodruff, sacre theologie professon", is its warden. He says he believes that in the first foundation of the hospital the warden and fellows thereof were priests professed of the order of the Holy Cross (cruciferarii) and that they nsed to wear the cross on their shoulders. Forty years ago one Master Darell, brother of John Darell, Knight, was warden of the hospital. In the time of his incumbency he and the three priests, his consocii, were professed and used to wear the cross. The present warden says that one of his consocii obtained papal leave to procure a benefice, and has done so by means of papal letters. The new master, Robert Woodruff, was appointed by the hing as former custodians had been. ${ }^{23}$

\section{Favershain. ${ }^{24}$}

The mandate to the Abloot and Convent of Faversham is dated 90 Sept. ${ }^{25}$ The prior, examined on the state of the house and on its observances, says that the alms of victuals and drink bestowed on the poor have been taken away by the monks, so that they are not given bountifully and largely to the poor, bat are distribated at one time or another amongst friends of the monks, according to the decision of the monks. Women have ingress to the cloister

$\overrightarrow{7}$ Who granted it to St. John's College, Cambridge. 7 Hen.8. It was for a master and three regular brethren, and two secular clerks. Dagdale, vi. 764.

at The house was founded 1147, for a convent of Cluniac monks brought from the priory of Bermondsey. The abbot was John Shepey, alias Cestelooke, the lest abbut of Faversham, from whon the commissioners of 1535 tried to wrest his house on the ground of his advanced age. Wright, Suppression of the Monastories, p. 103.

" Robert Favorsham is prior, the monks are John Preston, William Goodngnstone, cheplain, William Bidenden, subprior and chanter, John Bonghton, 6acrist, Thomas Lenham, collarer, Thomas Bermondsey, subchantar, Thomas Ware, William Barley, refectorarius, Robert Bendissh, John Hartey, subsacrist, Villiam Harnohill and Thomas Sollygn (thirteen in all). 
and to the refectory, and nre not shut out by cloors or gates as in other monasteries. A note is made to inquire into the number of monks according to the scheme of the foundation. John Preston, nged fifty-six, examined, says the old stipend is no longer paid in money, according to old custom, but in clothes. $\mathrm{He}$ begs that he may be relieved of the burden of his duties in the choir, for he stands professed of the said monastery forty-one years. William Bidenden, subprior, says the same about the stipend. Yet, he says, this payment in clothes and other nacessaries exceeds in value the sum of money paid them of old. But, he says, some avoid entering religion in that monastery because the stipend is not paid in money. He knows in this monastery sixteen pro. fessed monks, and has been there himself sixteen years. John Boughton, professed for fourteen years, says food and drink are not properly given to them in the refectory as they should be. $\mathrm{Ho}$ ngrees that the new 'exhibition' is worth more, but complains that they have nobody deputed to give them out elothes except the abbot, so that if they lack shoes or anything of the kind, they must all have reconrse to the abbot, to whom they think they ought not to go, but rather to an inferior person. If the stipend were peid in money, they would get a certain addition from their friends, which now they do not have, as all goes to the abbot. Thomas Lenham, cellarer, knows seventeen professed monks. He has been professed fifteen years. He agrees with Boughton on the impropriety of going to the abbot for clothes, quod non decct in animo suo "t dicit. Thomas Bermondsey, ton years professed of that house, says he has been punished for an offence according to rule, but besides this the abbot has deprived him of all his money. Now he has not a penny for anything. $\mathrm{He}$ thinks it is too severe. He knows sixteen monks professed there. Thomas Ware, professed of that house eleven years, knows seventeen monks. He says one Glover, butler (not a monk), is hostile to him and to almost all the monks in performing his office, and he was especially disagreeable at the time when the said Thomas was ill. William Barley says John Boughton is so rixosus et contumeliosus that he leads the monks into discord. He says each monk used to have certain mortuary fees in the said monastery. This money has been, and is still, taken away from them. Robert Bendisshe answered, as is shown in his bill. John Hartey, professed in that monastery, says that they have not enough clothing; for instance, each lacks a 'curtell' (anglice), and other provisions for keeping out the cold of winter. They do not have enough woollen shirts, nor in bed what are called 'straylles' (blankets), and whilst the clothes are at the wash they have to wear the same woollen clothes (stamina) in bed as they wore in the day. He says, further, that each monk should have one 
noble for the olit of one Bilsington; this noble was taken away from the witness last year. William Harnhill, professed, says that one Glover, who is butler, conducts himself badly in the convent-not as a servant, but rather as a master-he often makes complaints agninst the monks without cause; for instance, a certain monk sent a letter (misit literam missicam) to his parents by the said Glover, and he forthwith showed it to the abbot, pointing out to the prejudice of that monk that he should not have sent it. He says, also, that each monk in priest's orders used to have $40 d$., and each other monk 20d.; this was taken away from them last year. Robert Bendisshe and John Hartey do not give in their memoritoria as religious men should, bat they make up a book, and this is accepted as an acquittance of their returns. Thomas Sellyng, examined, says the cellarer does not provide good food for the refectory, and that the meat there is underdone, and only half roasted (carnes sunt rix semicocte et semiassarte). He says that Bendisshe is a blockhead (hebetis ingenii) and a poor scholar (parum cruditus), and that he is exempted from returning an account of his rents.

The injunctions order the abbot and convent to distribute alms in food and drink. Women are not to be allowed to come into the cloister, and no monk is to speak with any woman in the nave of the church. The abbot is to appoint a chamberlain, who shall provide the convent with the necessary clothes; it is too inferior an office for the abbot. Sufficient food and drink, and properly prepared, are to be provided in the refectory, especially on fast days. Each monk is to have two atamina and two 'strayles,' both for shirts and for blankets. The abbot is to give John Bermondsey the money which belongs to him from the obit of Bilsington. The abhot is enjoined not to exempt any from giving nccounts, anglice Rendryng (put in, we may suppose, for the benefit of the ignorant Bendisshe). The abbot should distribate to each monk his share of the money gained from the burials or obits of the deacl. William Boughton is warned to conduct himself modestly and charitably towards the brethren in future. The abbot is ordered to make Glover, the butler, behave himself better to the monks. The abbot is enjoined to let John Bermondsey enjoy the same liberty ns the other brethren enjoy. Then the archbishop warns the abbot to gire in his account of the state of the house before Easter next.

\section{Leedes. ${ }^{\text {xi }}$}

The mandate is to the Prior and Convent of the house and priory of the Blessed Mary and St. Nicholas at .Leedes. ${ }^{27}$ Richard Chetham, prior, says that all things are well observed

* House of Austin Canons.

I Richard Chetham is prior. The remaining fratres are John Bredgar, tormerly 
according to his commands. John Bredgar, formerly prior, is vicar of Marden at a distance of six miles from the monastery, and rarely comes to the monastery, but he says he thinks all things are well governed in that monastery. Thomas Vincent, subprior, says there is much that has been and has to be reformed in the house by the prior and subprior. John London is vicar of Stockbury. John Goldstone, professed of the house thirty years, says he performs the divine offices in the parish church of Bilsington which is appropriated to Bilsington priory. John Leicester, professed for thirty years, says that all is well, and so does Thomas Harietsham, professed of the house. Thomas Langley says the prior has taken away certain lights in the chapel of the Blessed Mary, for there were once ten wax lights burning before her image, and now the prior furnishes only five. ${ }^{28}$ The prior admitted William Parys, a Frenchman, to the brotherhood of the priory without the consent of his brethren. The prior sends a scholar to study [at the university] without consulting the brethren; the seniors ought to be convoked for that purpose. Further he says that what ought to be given for the souls of the founders is not distributed amongst the brethren. The prior presents chaplains to benefices without the consent of the brethren. He begs that the prior may not get the monastery into debt for lambs, mills, nor for repairing a bridge and especially the bridges of Rochester and Borstal.29 F. Thomas Egerton, examined, says that the prior does not punish his brethren according to the rule of St. Angustine but according to his own will, with passion, and by chastising them he does not correct but only excites them to anger, and if the brethren resist him in the punishings, the prior calls them all into the chapter-house and proclaims them heretics. $\mathrm{He}$ does not treat the brethren with fatherly love. Egerton begs that the prior may not seal with the common seal without the consent of the seniors.

J. Wodroff, examined, says the same about the use of the seal. The prior takes away every week the fee of $12 d$. from the brother celebrating high mass, and does not pay him. The brother celebrating high mass should have weekly the sam of $4 l l$. at the desire of William Clarke, as expressed in his will. The master of the grammar school receives certain moneys from the lands of master Clarke so that he teaches gratis. One Stephen Norton bequeathed to the brother celebrating high mass $4 d$. a week, and

prior, Thomas Vincent, subprior, Joln London, John Goldstone, John Leicestre, Thomas Harietsham, Thomas Langley, Thomas Egerton, John Wodrof, John Fortte, John Tenterden, John Fyneux, Robert Renham, John Maideston, William Parys, Thomas Broke, Thomas Chetham, John Bromfield, Bobert Ledes, Archelaus Comberland (twenty in all).

The charch was celebrated for this figare of the Virgin Marg. Dugdale, vi. 216.

- Baston MS. 
the prior takes the money aray contrary to the wish of the dead man. He begs the archbishop will ordain that tho prior must give a licence to the brethren to hare access to the person of the archbishop for the purpose of securing reforms, the licence being first procured of the prior. It was thus established by the Lord Cardinal Bourchier, bat the statute has been erased from the book, and John Maideston supports this. The infirm brethren are not well governed and have nobody to look after them.

John Fortte, professed of the priory of Launceston, in the diocese of Exeter, has been three years in this priory. He begs he may be sent back to the priory of Launceston, and that the archbishop will write for him to the Bishop of Exeter, that he may authorise his return to Launceston. John Tenterden. John Fyneux, professed here eight years, Robert Renham and John Bromficld aay all is well. John Maideston asks that the prior may correct in a more fatherly way, and not with so much severity. The prior does not make his account annually.

William Paris, a Frenchman, has been in the priory four years. He complains that the prior's accounts do not give details. The prior laid violent hands on him and kicked him (subpeditavit) and the prior forbade him to go to the lord [archbishop]. He begs that in future the prior may not apply his hands or feet to his brethren (non mittat manus et pedes in confratrez 8uos). On Tuesday last John Bromfield laid violent hands on him. Robert Leedes and Thomas Chetham complain of the prior's rigour; the prior had whipped Leedes outside the chapter-honse, in the refectory, and Chetham finds the brethren are punished too sererely when they complain that the meat and fish are badly serred. Archelaus Comburland is not professed; Thomas Broke is a brother of Bilsington, and has been at Leedes one year.

The injunctions order the prior to seal nothing with the common seal for which he has not the consent of the senior bretbren, or at least without the consent of the larger and saner number of his brethren. He must give annually his account in writing to the brethren. The prior, subprior, and all the officers are to punish with fatherly love, not with rigour. The prior is to give licences to the brethren to appeal to the archbishop on questions of reform; a deputy from the prior is to accompeny the brother who gets the licence. The prior is to burn ten wax lights before the image of the Blessed Virgin. $\mathrm{He}$ is to pay the sam weekly to the brother celebrating high mass from the bequests of Norton and Stephen Clarke, and 12d. weekly to the chaplain celebrating for the soul of Nicholas Potyn, as in the book of Henry Chichele, formerly archbishop, under a fine of $4 l$. sterling to the archbishop. The prior is to pay a teacher to instruct the more youthful of the brethren. 
The risitation of the Prior and Convent of Bilsington ${ }^{30}$ took place Sept. 24. Nothing is said about the condition of the house.

Shepey.

15. On Oct. 2, the visitors were in the chapter-house of tho Prioress and Convent of Shepey." Agnes Pevers, prioress, say's all is in good order, except that she doubts whether Anicia Tanfeld, cantarista, behaves well to the sisters, and whether she provides properly for the observances in the choir. Being asked about the number of nuns in the convent, she says she has heard there were serenteen. She knew of fourteen; she herself wished to increase the number to fourteen (sic) if she could find any who wisherl to enter religion.

Agnes Norton, sulpprioress, sags they have- no maid-servant. whose duty it is to serve the convent with food and drink and other necessmies, but the house is serred by a woman, an outsider from the town. There is no house for the infirm (anglice, Fermory), but those who are ill die in the dormitory. She knows of fifteen nuns and has heard of serenteen. The gate of the cloister is closed too strictly, not only after supper, bat at the time of divine service. The prioress does not give any accounts. Indeed she has nevor heard of any account being given. Anicia Tanfeld says that they hare no maid called the Covent Servante, whose duty, as it uscd to be of old time, was to serve the nuns with food and drink and to wash their clothes, wherefore the stipend of every person in the convent is diminished. The gate of the cloister is closed in. mediately after the bell rings for respers and remains slrut until it rings for prime ; this, in the opinion of the convent, is too strict, especially in summer-time, becsuse it might remain open until after supper, as she says. The prioress does not render her accounts to the convent. 'They have no domum infirmorum (anglice, a Fermory). Elizabeth Chatok, cantarista, says they have no famulam deputatam (anglice, a Covent seruante), and makes the same complaint about the door, clauditur nimis tempestive tempore presertim estiuali. Elizabeth Stradlyng says the same about the servant. There is no infirmary, but the prioress means to baild one as soon ats she conveniently can. The accounts are not properly rendered. She says the menservants of the prioress do not behare properly to the convent, but they speak of the convent contemptuously and dishonestly, thus ruining the convent.

Mildred Wigmor says the cloister door is closed before vespers. For lack of a servant their stipend is diminished 28. a year, paid to the washerwoman, and the nuns cannot go out and fetch necessaries. Dorothea Darell says the door of the cloister is shat

- Priory of Augtin Canons. Dagdale, ri. 492. 
directly after they have gone to vespers. Agnes Bolney says all is well. Anna Petitt notices the lack of (anglice) a convent-woman, who is wanted especially in time of sickness. However, one of the convent does serve them, leaving her place in the kitchen for the refectory. She agrees with Dorothea Darell that the prioress does not render accounts. There used to be seventeen nuns. When they are ill they have to hire women for themselves and pay them out of their own money. The door of the cloister is closed directly after the bell rings for vespers. Ursula Gosborn says all is well.

The injunctions issued by Cuthbert Tunstall, who conducted the inquiry, make the usual order that the prioress render accounts to the convent and to the archbishop with an inventory. She is to provide an honest woman-servant. She must make up the number of the house to fourteen as soon as she conveniently can, ${ }^{32}$ and build an infirmary at her earliest convenience, before any other buildings. The nuns mast make the accustomed repair of the chancel of Bobbing before the Feast of St. John the Baptist's Nativity under the penalty of the law.

\section{Maidstone.}

The next mandate is directed to the Master and Fellows of the College of Maidstone, on 6 October; the prior and officers are warned to make full accounts and inventories, and the college is to show its right to the appropriations of Sutton, Linton, and Farleigh churches. ${ }^{33}$

\section{Cumbrcell.}

The last visitation belongs to the next year, 3 June, 1512. The mandate is to the Prior and Convent of the house or priory of canons at Cumbwell. ${ }^{34}$ Tunstall was visitor and held his inquest in the chapter-house. He finds Thomas Patenden is prior, and has been for thirty-two years. He is examined on the articles of his religion and the state of his priory. John Halynbery, professer in the said house for twenty-five years, says all is well as far as he has noticed. John Sohepey, professed for thirty years, says the infirmary is in great need of repairs. Nobody is deputed to tend the sick. He has not enough clothes for his body. He had been ill two years and had not had the necessary food. He says also Roger Maidstone, canon, laid violent hands on him about the Fesst of the Conception of the Blessed Virgin Mary last

- At the dissolution there were ten nuns and the prioress, so a slight improvement had been made. Dugdale, ii. 50 .

- Tunstall visited, examining in the restibule. Master William Grocyn, B.D., is master, Giles Rede sub-master, Thomas Nicolls chaplain and fellow, Robert Ward the same, David Knowdisley seneschal and fellow and rector of Cradsle, Thomas Banson chaplain and fellow, John Cotyn the asme.

* Order of Bt. Augratine. 
year. A memorandum is made, that the prior never accounts for the state of the said priory in the presence of his brethren. 1)om. John Lanny, professed for twenty-four years, says there is not enough to eat and drink, there is no provision for the infirm in the infirmary, and when they fall ill they must lie in thu dormitory. The canons do not know the state of the priory, and the prior never renders any account. He had received from the papal court a capacity to receive a priory and also a benefice in commendan, and says he hes done so with the licence of the prior. The capacity remains in the hands of the vicar of Ticehurst. ${ }^{35}$ The manors of Benenden ${ }^{x}$ and Thurnham ${ }^{37}$ need great repairs owing to the neglect of the prior. They have not the necessary clothing, nor any money to mend what they have.38 The prior and convent laid him under a debt of 40l. in an obligation without any condition to Robert Rede, justice of the king, and to a certain Weldisshe senior near Maideston, which obligation remains in the hands of the minister of Mottenden, and the convent arranged by a special mandate and request of the said prior so that the said house should not be indebted to the said Robert Rede and Weldysshe. John Lyndesey, professed there twenty-four years, says the infirmary is not repaired. Roger Maidston, deacon, professed there six years, says the infirmary needs repair, otherwise all is well as far as he has noticed, but there is not enough to eat and drink nor enough clothes. William Wadeherst, acolyte, professed six years, says there is no teacher of grammar.

The injunctions order a proper account and inventory. Sufticient repairs are to be made to enable the sick canons to use the infirmary before the Feast of All Saints: Suitable attendants are to be provided for the sick, and the canons must have enough food and drink and good clothes, according to the raie of religion, also there must be a teacher of grammar for the canons before the Feast. of the Nativity of St. John the Baptist. The manors are to be repaired. The prior says the obligation made between Dom. Robert Reed and Weldysshe, remaining in the hands of the minister of the house of Mottenden, is cancelled. $\mathrm{He}_{\theta}$ is to show the cancelled obligation to the archbishop.

Here the visitation ended. Its list of complaints ccntains many that are ludicrously human-many that might come' from any body of persons enjoying a state charity at the present day. They lend no support to the theory that the inmates of religious houses were steeped in inhuman wickedness. On the other hand, the decay of the monsstic spirit is obvious throughont.

\section{Marzy Bateson.}

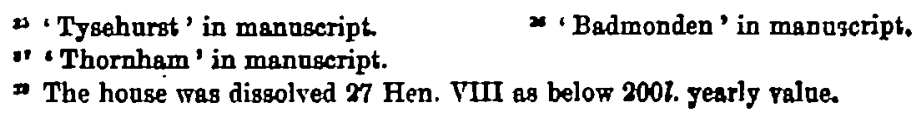

